\title{
Effects of regulated deficit irrigation on the growth and berry composition of Cabernet Sauvignon in Ningxia
}

\author{
Rui Wang ${ }^{1,3}$, Pengke Yan $^{1}$, Quan Sun ${ }^{1}$, Baofeng Su², Junxiang Zhang ${ }^{3 *}$ \\ (1. School of Agronomy, Ningxia University, Yinchuan 750021, China; \\ 2. College of Mechanical and Electronic Engineering, Northwest A\&F University, Yangling 712100, China; \\ 3. Ningxia Grapes and Wine Research Institute, Yinchuan 750021, China)
}

\begin{abstract}
The adoption of water-saving irrigation strategies is required particularly for wine grape variety, which has been widely cultivated in arid and semiarid areas. To assess vine response to regulated deficit irrigation (RDI), the grape growth and berry composition under five treatments that irrigated at a certain percentage of the crop evapotranspiration $\left(\mathrm{ET}_{\mathrm{c}}\right)$ were evaluated over a 3-year period in a vineyard with the grape variety of Cabernet Sauvignon. The results indicated that RDI had a significant effect on the grape berry size and yield. The largest berry size $(12.20 \mathrm{~mm})$ was obtained under the T50 in 2014 , while the smallest berry size $(9.83 \mathrm{~mm})$ one was obtained under the CK treatments in the same season. The highest individual yield occurred in the T50 treatment, with an average of $1.99 \mathrm{~kg}$, followed by the T25-50 treatment. However, both weights were significantly larger than that of the CK treatment. Compared with the T50 treatments, the individual grape vine yield in the T50-25 treatments were slightly less by $16.9 \%$ for $2013,15.3 \%$ for 2014 and $18.1 \%$ for 2015 . Compared to control (CK) treatment, the soluble solid and reducing sugar contents decreased, the total acid content increased, and the sugar/acid ratio basically showed a downward trend. The treatment irrigated at $50 \% \mathrm{ET}_{\mathrm{c}}$ until veraison and $25 \%$ thereafter $(\mathrm{T} 50-25)$ increased the phenolic compound content in grape skins. The treatment received only rain water during the grape growing season (CK) and the one irrigated at $25 \%$ of the $\mathrm{ET}_{\mathrm{c}}$ crop evapotranspiration (T25) caused defoliation and negatively affected the yields and grape composition during all 3 years. Therefore, the RDI not only inhibited the vine vegetative growth but also improved the fruit quality. In terms of productivity and grape composition, the Cabernet Sauvignon grape variety was most sensitive to water stress post-veraison. Over the comprehensive consideration of yield, water-use efficiency and berry composition, the T50-25 treatment was the most efficient irrigation strategy in this area.
\end{abstract}

Keywords: regulated deficit irrigation, Cabernet Sauvignon, arid area, grape composition DOI: $10.25165 /$ j.ijabe.20191206.5206

Citation: Wang R, Yan P K, Sun Q, Su B F, Zhang J X. Effects of regulated deficit irrigation on the growth and berry composition of Cabernet Sauvignon in Ningxia. Int J Agric \& Biol Eng, 2019; 12(6): 102-109.

\section{Introduction}

Water is indispensable source and highlighted topic for the studied vineyards, especially in semi- and arid ecosystems ${ }^{[1]}$. The sustainable utilization of available water will be a major challenge for worldwide future water policy as water resources become increasingly scarce ${ }^{[2,3]}$. Different irrigation techniques have been widely used to conserve water in worldwide land cultivation, as a perennial plant, the soil water storage, conditions and quality are the main hydrological key factors for grapevines in semiarid and arid areas. The most promising technique, RDI can improve water use efficiency (WUE) of grapevines and reduce the vegetative growth, which may affect berry composition, especially polyphenols and aroma ${ }^{[4-7]}$. The vineyard conditions, such as soil

\section{Received date: $2019-06-17 \quad$ Accepted date: $2019-11-10$}

Biographies: Rui Wang, $\mathrm{PhD}$, Associate Professor, research interests: grape soil fertilizer and water regulation management, Email: amwangrui@126.com;

Pengke Yan, MS, research interests: grape nutrition and agricultural resource utilization, Email: yanpengke1993@163.com; Quan Sun, PhD, Professor, research interests: grape soil fertilizer and water management. Email: sqnxu@sina.com. Baofeng Su, PhD, Assistant Professor, research interests: grape water and fertilizer monitoring. Email: bfs@nwsuaf.edu.cn.

*Corresponding author: Junxiang Zhang, PhD, Professor, research interests: grapes and wine. Ningxia Grapes and Wine Research Institute, Yinchuan 750021, China. Tel: +86-13895013338, Email: nxzhangjunxiang@126.com; texture and depth, atmospheric environment, variety, irrigation scheduling and viticulture practices that makes it difficult to predict the best timing for imposing water deficits ${ }^{[8]}$. Mild water stress is considered beneficial for improving grape quality, particularly for wine brewing ${ }^{[9-11]}$. For premium wine production, the emphasis shifts toward fruit composition, which is responsive to a certain degree of plant water stress during sensitive growth and ripening periods. It has been found that RDI can alter the vine physiology and plant chemical signaling systems to obtain horticultural benefits, such as improving crop water utilization, conserving irrigation water and increasing fruit quality ${ }^{[8,12]}$. In this viticultural context, RDI has emerged as a potential strategy for improving the cluster microclimate, reducing the berry size and increasing the sugar and polyphenol contents ${ }^{[13,14]}$.

However, severe water stress could be detrimental to fruit composition due to poor canopy development and a reduced leaf assimilation rate, thus leading to an inadequate vine capacity to ripen the crop ${ }^{[13,15]}$. Most researchers found that a pre-veraison water shortage leads to the accumulation of higher phenolic contents in grapes, as well as much lower yields ${ }^{[7,16,17]}$. A slight improvement in grape anthocyanin concentrations was reported, while the result was not conclusive in suggesting the appropriateness of post-veraison water stress ${ }^{[17]}$. In contrast, RDI can control excessive vegetative development and reduce the berry size by a pre-veraison water deficit. Consequently a moderate 
post-veraison water deficit can stimulate the direct accumulation of anthocyanins and other phenolic compounds ${ }^{[18]}$. The results of imposing water restrictions during pre-veraison and post-veraison were studied, and the best period for imposing water restrictions was identified according to the desired grape composition style and available irrigation water amount ${ }^{[19]}$. The researches of the Cabernet Sauvignon grape varieties in Spain and USA indicated that water deficits maintained over a period of 5 years led to a gradual reduction in the yield and vegetative growth, but without major changes in the grape composition ${ }^{[8]}$. It was found that in vineyards regulated by deficit irrigation did not obtained any significant effect on berry size and yield, but had great effect on the berry composition and fruit soluble solids, the sugar contents and sugar-acid ratio increased but the total acid content decreased $^{[6]}$. Other researches demonstrated that RDI plays a significant role in promoting phenolic compounds, soluble solids and anthocyanin synthesis ${ }^{[20]}$. Moderate water deficits play a direct role in promoting wine composition by improving grape color, flavor and flesh ${ }^{[21]}$. Anthocyanin accumulation in grape skin tissues begins at veraison, but it is also proved that pre-veraison water stress also affects the anthocyanin synthesis pathway ${ }^{[13,22]}$. The berry solute content increases with berry size, however, the correlation between these variables is not linear, larger berries showing lower soluble solids ( ${ }^{\circ}$ Brix values) and anthocyanin concentrations than those of smaller berries ${ }^{[23]}$. While, it is also reported inversely that highest yield will happened with most irrigated plants ${ }^{[15]}$. A moderate water deficit is normally preferred in cool areas to control shoot vigor and to permit sugar translocation to the grape clusters, which will result in improved ripening, higher ${ }^{\circ}$ Brix values, lower malic acid concentrations and more intensely colored wines ${ }^{[24]}$. Precise irrigation scheduling allows growers to achieve several objectives, such as water conservation, optimum grape size, and grape polyphenol content ${ }^{[23,25,26]}$. However, the response of vines to the timing of irrigation cannot be guaranteed ${ }^{[19]}$.

As a perennial plant, the response of grapevines to environmental conditions mostly depends on events that occurred during the previous growing season. Therefore, it is advisable to design an experiment plan with at least three years to study the response to different irrigation strategies, as some trends may only appear after a lengthy adaptation period, a longer-term experiment will yield more reliable information. In the Helan Mountain vineyards, the rainfall was limited, so the normal growth of wine grapes must be maintained through artificial irrigation. Moreover, in the same season of rain and heat in this region, percentage of ETc value method was adopted to set the percentage of deficit irrigation period and deficit degree, which can effectively improve the grapes physiological conditions that promote the improvement of berry quality. The aim of this study was to determine the effects of RDI on the vegetative growth, yield, and berry composition on Cabernet Sauvignon vines in the Helan Mountain vineyards using field trial method during year 2013 to 2015 .

\section{Materials and methods}

\subsection{Experimental area}

This study was conducted at the experimental station of Grape and Wine Engineering Research Centre of the Education Ministry in Ningxia (NW China) $\left(38^{\circ} 43^{\prime} \mathrm{N}\right.$; $106^{\circ} 45^{\prime} \mathrm{E}, 1100 \mathrm{~m}$ a.s.l.). The region is characterized by a temperate continental semiarid climate with an annual frost-free period of approximately $157 \mathrm{~d}$. The annual average temperature was $8.5^{\circ} \mathrm{C}$, extreme maximum temperature $37.7^{\circ} \mathrm{C}$, extreme minimum emperature was $25.9^{\circ} \mathrm{C}$, the highest average was $23.4^{\circ} \mathrm{C}$ in July and the lowest average was $-7.9^{\circ} \mathrm{C}$ in January. The average temperature during the grape growing season was $18.2^{\circ} \mathrm{C}$. The annual rainfall over the last 10 years averaged $185 \mathrm{~mm}, 80 \%$ of which occurred between June and August. The evaporation in the area is high; with an annual reference potential evapotranspiration of $2262.2 \mathrm{~mm}$ (Data was from Yongning weather bureau statistics). Vitis vinifera L. cv. Cabernet Sauvignon have been cultivated for 7 years before this study. The vine rows were oriented north to south, with $3.0 \mathrm{~m}$ between the rows and $1.0 \mathrm{~m}$ between the vines. All of the grapevines were drip-irrigated with dripper spacing of $0.5 \mathrm{~m}$, and the dripper outputs was $2.7 \mathrm{~L} / \mathrm{h}$. The annual and month rainfall from 2013 to 2015 is shown in Figure 1.

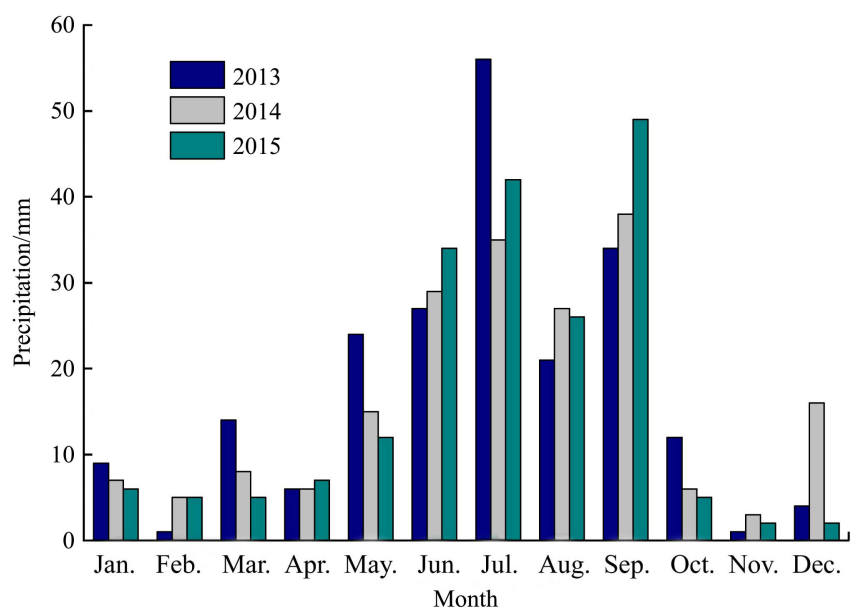

Figure 1 Monthly precipitation during the studied period

According to the Chinese soil classification system, the study area belongs to the aeolian soil. Through the early field determination can find that the study area soil water holding capacity was lower, the $0-20 \mathrm{~cm}$ layer water holding capacity was $16 \%, 20-40 \mathrm{~cm}$ was $18 \%$ and the $40-60 \mathrm{~cm}$ was $13 \%$. The soil bulk density was heavier, the $0-20 \mathrm{~cm}$ layer was $1.35 \mathrm{~g} / \mathrm{cm}^{3}, 20$ $40 \mathrm{~cm}$ was $1.45 \mathrm{~g} / \mathrm{cm}^{3}$ and the $40-60 \mathrm{~cm}$ was $1.39 \mathrm{~g} / \mathrm{cm}^{3}$.

\subsection{Experimental design}

In the five years before the trial began, we continuously monitored the transpiration data of the viticultural region with Cabernet Sauvignon and obtained the average crop evapotranspiration $\left(\mathrm{ET}_{\mathrm{c}}\right)$. Based on this, five irrigation treatments were imposed according to the percentage of ETc value over three consecutive years: (1) non-irrigation, as control (CK), which received only rain water during the grape growing season (To ensure the normal growth of grape, the grapes under CK was irrigated $300 \mathrm{~m}^{3} / \mathrm{hm}^{2}$ before winter bury and spring come out), (2) irrigated at $25 \%$ of the $\mathrm{ET}_{\mathrm{c}}$ crop evapotranspiration $\left(\mathrm{ET}_{\mathrm{c}}\right)$ (T25), (3) irrigated at $50 \% \mathrm{ET}_{\mathrm{c}}$ until veraison and $25 \%$ thereafter (T50-25), (4) irrigated at $25 \%$ of the $\mathrm{ET}_{\mathrm{c}}$ until veraison and $50 \%$ thereafter (T25-50), (5) irrigated at 50\% $\mathrm{ET}_{\mathrm{c}}$ (T50). The different irrigation amount was established from $\mathrm{ET}_{\mathrm{c}}$ measurements at the experimental site to maintain a moderate water deficit levels. ETc was calculated using the Pennman-Monteith model ${ }^{[27]}$. Treatments were distributed according to a completely randomized block design with five replications. The treatments were drip irrigated, details see Table 1. Besides, the vines of all treatments were cultivated the same according to usual criteria for this area. 
Table 1 Table of regulated deficit irrigation schedule

\begin{tabular}{|c|c|c|c|c|c|c|c|}
\hline Treatment & Germination stage & Flowering stage & Expand stage & Veraison stage & $\begin{array}{l}\text { Unit irrigation amount } \\
\qquad / \mathrm{m}^{3} \cdot \mathrm{hm}^{-2}\end{array}$ & Irrigation times & $\begin{array}{c}\text { Irrigation amount } \\
\qquad / \mathrm{m}^{3} \cdot \mathrm{hm}^{-2}\end{array}$ \\
\hline CK & - & - & - & - & 300 & 2 & 600 \\
\hline $\mathrm{T} 25$ & + & + & + & + & 120 & 12 & 1440 \\
\hline T50-25 & ++ & ++ & + & + & $240 / 120$ & 12 & 2160 \\
\hline $\mathrm{T} 25-50$ & + & + & ++ & ++ & $120 / 240$ & 12 & 2160 \\
\hline
\end{tabular}

Notes: "-"represents no irrigation, "+" represents irrigated at 25\% ETc, "++" represents irrigated at 50\% ETc. To ensure the normal growth of grape, the grapes under CK was irrigated $300 \mathrm{~m}^{3} \cdot \mathrm{hm}^{-2}$ before winter bury and spring come out; Normal treatments was irrigated 12 times with unit amount of $480 \mathrm{~m}^{3} \cdot \mathrm{hm}^{-2}$.

\subsection{Determination of grape vice sought incidence and shoot length}

At the fruit veraison during every August $5^{\text {th }}, 30$ vines were selected to measure the quantity of main shoots and lateral shoots, and calculate the vice sought incidence (the ratio of lateral shoot number and leading shoot number). To estimate the plant vigour, the lengths of new shoot were measured from 30 vines of each treatment to evaluate the shoot length at every June $20^{\text {th }}$ during the summer pruning.

\subsection{Determination of grape leaf water potential}

During the fruit veraison, the pressure chamber (PMS) (600D China) was used to monitor the grape leaf water potential (LWP) for a complete irrigation circle. It was monitored every 2 hours from 8:00 to 20:00 on six sunny leaves per treatment.

\subsection{Measurements of Grape Berry size}

At September $25^{\text {th }}, 30$ grape berry were randomly selected from the upper, middle and lower parts of the grape vine, and 90 pieces were selected for each treatment. The transverse diameter of the fruit was measured with a vernier caliper.

\subsection{Yield}

Total yield was determined by the cluster weight of randomly selected 30 vines for each treatment during the harvest stage (from September $25^{\text {th }}$ to October $3^{\text {rd }}$ ), the unit yield of each vine was also recorded.

\subsection{Determination of grape composition}

During the grape maturity period, clusters at the same direction and same position of 10 randomly selected vines were labeled, and then collect fruit from the upper, middle and lower parts on the cluster for quality measurement. For each replicate, an individual vine yield was weighed, and then kept frozen to analyze the tannins and anthocyanins. The remaining grape sample was transferred to a cool storage area and used as soon as possible. Soluble solids were determined using a ${ }^{\circ}$ Brix refractometer (PR32 Atago Co. Ltd., Japan). Reducing sugars were determined using titration with 3, 5-Dinitrosalicylic acid, and titratable acidity was determined using standardized $0.1 \mathrm{~N} \mathrm{NaOH}$ (end-point $\mathrm{pH} 8.2$ ). The $\mathrm{pH}$ of the juice was recorded using a Metmorph 702 SM automatic neutralizer (Titrino, Herisau, Switzerland). Whole grapes from the frozen samples were homogenized and analyzed for their anthocyanin, tannin, and iron-reactive phenolic concentrations. Tannins were determined by folin-denis method, total phenols by folin-Ciocalteau method and anthocyanins by $\mathrm{pH}$ differential method $^{[28]}$.

\subsection{Statistical analysis}

Significant differences among the groups were determined via an analysis of variance (ANOVA) using the SAS 8.1 (SAS Institute Inc., Cary, NC, USA). The difference between treatments was analyzed and compared by using the Least-Significant Difference (LSD) method at the 0.05 probability level.

\section{Results}

\subsection{Effects of RDI on grape LWP}

The LWP of 2 complete irrigation circles during flowering and veraison was measured. Results showed a linear decrease from the end of this irrigation event until next irrigation (Figure 2 and Figure 3). The LWP of CK was not affected by irrigation, and kept at a stabled range close to $-16 \mathrm{MPa}$. The LWP of T25 and T25-50 decreased quickly at flowering stage due to water stress. The grape water requirement during veraison was lower than that of flowering stage, thus, the LWP were higher under all treatments at veraison (Figures 2 and 3). There is no precipitation occurred during the monitoring period, the LWP was different between each study year, it was high in 2014 than that in 2013 and 2015, and there is no significant difference between 2013 and 2015.

2013
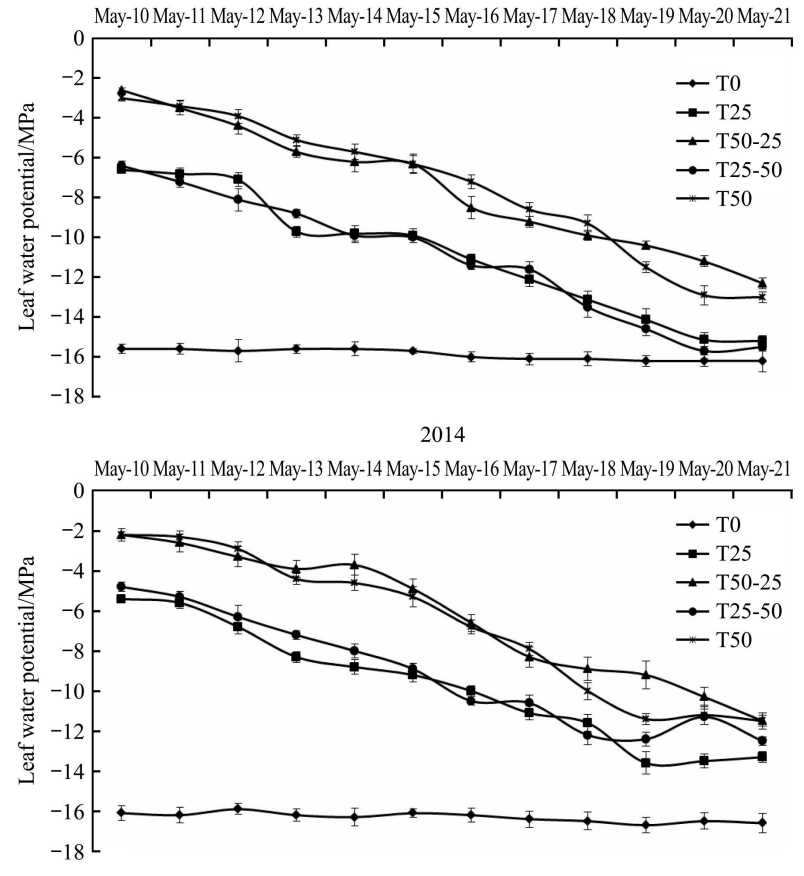

2015

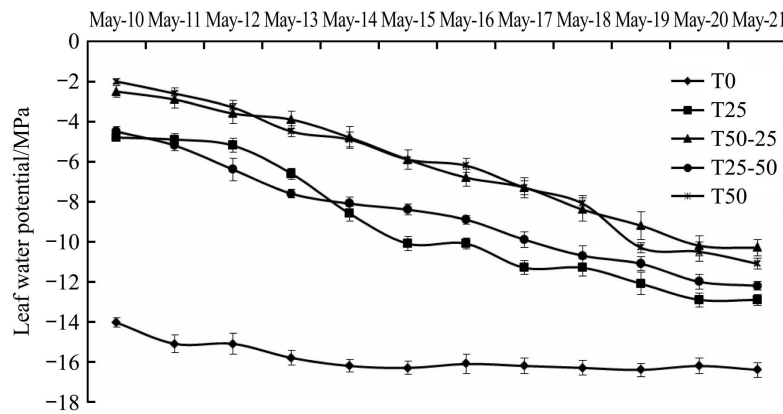

Figure 2 Leaves water potential change under RDI during flowering stage 
2013

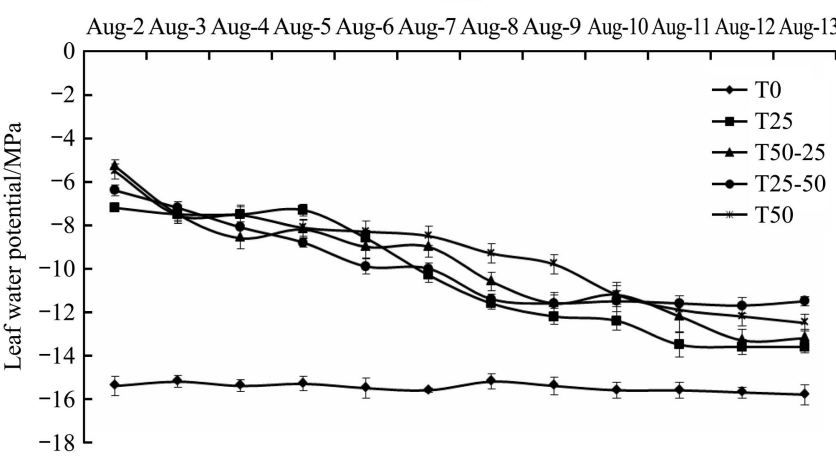

2014

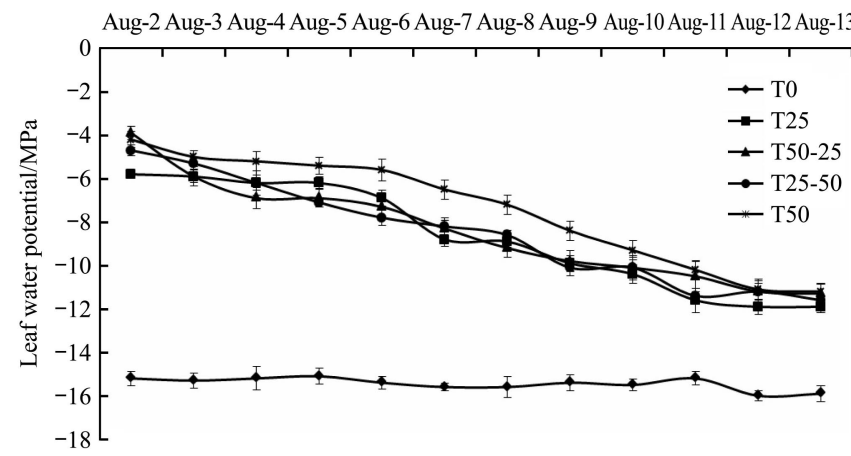

2015

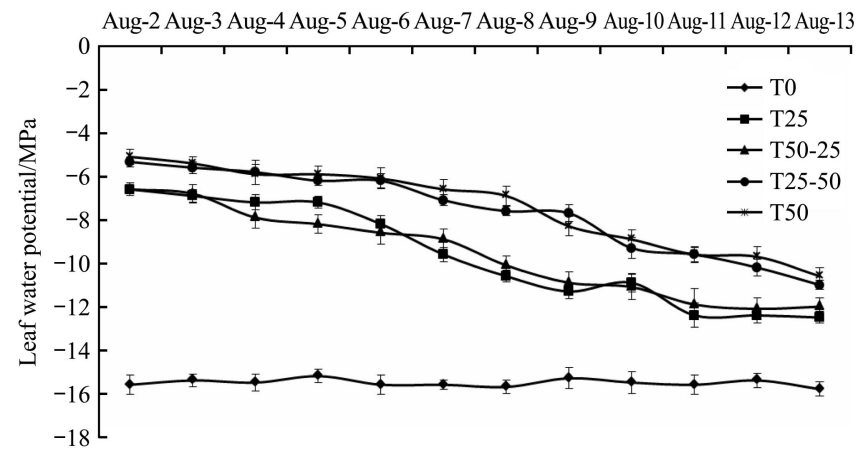

Figure 3 Leaves water potential change under RDI during veraison stage

\subsection{Effects of RDI on shoot length and the vice sought incidence}

The vegetative growth or plant vigor estimated via the grape shoots was less sensitive than the yield components to variations in water availability; thus, the water availability substantially affected the grape growth, with significant differences recorded in the final year of the study. Most of the differences were observed after the third year of the study, the average length of the plant shoots under CK treatment just have $8.0 \mathrm{~cm}$ which was significantly lower than that of the other treatments. The average shoot length of the T50 treatments achieved $53.3 \mathrm{~cm}$ which was longest among the others. Although the average shoot lengths about $30.1 \mathrm{~cm}$ of the T25-50 treatment was shorter than that about $35.5 \mathrm{~cm}$ of the T50-25 treatment, the difference was not significant. It can be found from Table 2 that, with the water stress increase, the incidence of all treatments grape vice sought decreased. The shoot length and vice sought incidence of CK were both lower than others. The fresh shoot length and vice sought incidence of T25 and T25-50 were significantly lower than those under T50-25 and T50, which indicates that the grape vice sought incidence was more sensitive to the water deficit at the early growth stage. The rainfall amount was varied during year 2013 to 2015 , while the majority rainfall mainly occurred every July, August, and September (Figure 1), and the grape vines has been developed completely.

There was no significant difference of grape vice sought incidence between the studies years, which indicated that the RDI will not affect grape vice sought incidence with the years of RDI applied. Besides, the all average grape vice sought incidence was under 3.7, which largely decreased the cost of grape pruning (Table 2)

\subsection{Effects of RDI on Grape Cluster Number and Individual Grape Yield}

The number of cluster and the unit cluster weight together decided the grape yield. There was no significant difference in average cluster number (over 19.7) between the RDI treatments except CK (Table 3). Generally speaking, the yield reduction was mostly correlated with unit cluster weight decrease.

Table 2 Effects of the RDI treatments on the plant shoots and grape vice sought incidence (450 samples)

\begin{tabular}{|c|c|c|c|c|c|c|c|c|}
\hline \multirow{2}{*}{ Treatment } & \multicolumn{3}{|c|}{ Plant shoots $/ \mathrm{cm}$} & \multirow{2}{*}{$\begin{array}{l}\text { Mean annual } \\
/ \mathrm{cm}\end{array}$} & \multicolumn{3}{|c|}{ Grape vice sought incidence $/ \%$} & \multirow{2}{*}{$\begin{array}{c}\text { Mean annual } \\
/ \%\end{array}$} \\
\hline & 2013 & 2014 & 2015 & & 2013 & 2014 & 2015 & \\
\hline $\mathrm{CK}$ & $7.8 \pm 0.3 \mathrm{~d}$ & $7.0 \pm 0.7 \mathrm{~d}$ & $8.0 \pm 0.4 \mathrm{~d}$ & $7.6 \pm 0.5 \mathrm{~d}$ & $1.3 \pm 0.1 \mathrm{c}$ & $1.1 \pm 0.0 \mathrm{c}$ & $1.2 \pm 0.1 \mathrm{c}$ & $1.2 \pm 0.1 \mathrm{c}$ \\
\hline $\mathrm{T} 25$ & $17.3 \pm 1.8 \mathrm{~d}$ & $12.5 \pm 1.1 \mathrm{c}$ & $14.5 \pm 1.7 \mathrm{c}$ & $14.8 \pm 1.3 \mathrm{c}$ & $2.8 \pm 0.2 b$ & $2.6 \pm 0.3 b$ & $2.4 \pm 0.2 \mathrm{~b}$ & $2.6 \pm 0.2 \mathrm{~b}$ \\
\hline $\mathrm{T} 50-25$ & $39.3 \pm 2.2 b$ & $32.3 \pm 2.6 \mathrm{~b}$ & $35.0 \pm 4.4 \mathrm{~b}$ & $35.5 \pm 2.9 \mathrm{~b}$ & $3.3 \pm 0.1 \mathrm{a}$ & $3.3 \pm 0.2 \mathrm{a}$ & $3.4 \pm 0.3 \mathrm{a}$ & $3.3 \pm 0.2 \mathrm{a}$ \\
\hline $\mathrm{T} 25-50$ & $28.0 \pm 2.0 \mathrm{c}$ & $29.3 \pm 2.4 \mathrm{~b}$ & $33.0 \pm 2.8 \mathrm{~b}$ & $30.1 \pm 2.4 \mathrm{~b}$ & $2.3 \pm 0.3 \mathrm{~b}$ & $2.9 \pm 0.1 \mathrm{~b}$ & $2.2 \pm 0.2 \mathrm{~b}$ & $2.5 \pm 0.2 b$ \\
\hline $\mathrm{T} 50$ & $54.3 \pm 3.7 \mathrm{a}$ & $52.5 \pm 4.6 \mathrm{a}$ & $53.0 \pm 4.7 \mathrm{a}$ & $53.3 \pm 4.3 \mathrm{a}$ & $3.5 \pm 0.2 \mathrm{a}$ & $3.9 \pm 0.3 \mathrm{a}$ & $3.6 \pm 0.2 \mathrm{a}$ & $3.7 \pm 0.2 \mathrm{a}$ \\
\hline
\end{tabular}

Note: Means within a column in the same year followed by the same letters are not significantly different $(p=0.05, n=5)$

Table 3 Effects of the RDI treatments on the cluster number and individual grape yield (450 samples)

\begin{tabular}{|c|c|c|c|c|c|c|c|c|}
\hline \multirow{2}{*}{ Treatment } & \multicolumn{3}{|c|}{ Cluster number per vine } & \multirow{2}{*}{ Mean annual } & \multicolumn{3}{|c|}{ Individual grape yield $/ \mathrm{kg}$} & \multirow{2}{*}{$\begin{array}{c}\text { Mean annual } \\
/ \mathrm{kg}\end{array}$} \\
\hline & 2013 & 2014 & 2015 & & 2013 & 2014 & 2015 & \\
\hline $\mathrm{CK}$ & $15.4 \pm 0.2 b$ & $15.9 \pm 1.4 \mathrm{~b}$ & $13.6 \pm 3.2 b$ & $15.0 \pm 2.1 \mathrm{~b}$ & $0.98 \pm 0.09 \mathrm{c}$ & $1.07 \pm 0.03 \mathrm{c}$ & $1.09 \pm 0.33 \mathrm{~d}$ & $1.05 \pm 0.12 \mathrm{c}$ \\
\hline $\mathrm{T} 25$ & $20.3 \pm 0.7 \mathrm{a}$ & $19.4 \pm 0.6 \mathrm{a}$ & $19.5 \pm 0.9 \mathrm{a}$ & $19.7 \pm 0.8 \mathrm{a}$ & $1.63 \pm 0.15 b$ & $1.58 \pm 0.14 \mathrm{~b}$ & $1.58 \pm 0.08 \mathrm{c}$ & $1.60 \pm 0.12 b$ \\
\hline T50-25 & $20.9 \pm 0.5 \mathrm{a}$ & $20.2 \pm 1.1 \mathrm{a}$ & $19.9 \pm 4.2 \mathrm{a}$ & $20.3 \pm 2.3 \mathrm{a}$ & $1.67 \pm 0.14 \mathrm{~b}$ & $1.66 \pm 0.17 \mathrm{~b}$ & $1.63 \pm 0.15 \mathrm{c}$ & $1.65 \pm 0.16 \mathrm{~b}$ \\
\hline $\mathrm{T} 25-50$ & $20.8 \pm 0.4 \mathrm{a}$ & $21.3 \pm 2.3 \mathrm{a}$ & $21.1 \pm 2.7 \mathrm{a}$ & $21.1 \pm 1.8 \mathrm{a}$ & $1.91 \pm 0.20 \mathrm{a}$ & $1.91 \pm 0.19 \mathrm{a}$ & $1.85 \pm 0.02 b$ & $1.89 \pm 0.04 \mathrm{a}$ \\
\hline
\end{tabular}

Note: Means within a column in the same year followed by the same letters are not significantly different $(p=0.05, n=5)$ 
The average weight of unit vine under water deficit was listed in Table 3. It can be found that the grape weight for an individual vine decreased with increased RDI levels during the 3 years. The highest individual yield occurred in the T50 treatment, with an average of $1.99 \mathrm{~kg}$, followed by the T25-50 treatment. There was no significant difference in the individual vine weight between the T50-25 and T25 treatments; however, both weights were significantly larger than that of the CK treatment, and notably less than the weights of the T25-50 and T50 treatments. Compared with the T50 treatments, the individual grape vine yield in the T50-25 treatments were slightly less by $16.9 \%$ for $2013,15.3 \%$ for 2014 and $18.1 \%$ for 2015 (Table 3). The individual grape weight in the CK treatment was relatively low, with an average of $1.05 \mathrm{~kg}$ for the three years.

\subsection{Effects of RDI on grape berry size}

As shown in Table 4, the grape fruit diameters tended to decrease with RDI increase. The largest grape diameter $(12.20 \mathrm{~mm})$ was obtained under the T50 in 2014, while the smallest grape $(9.83 \mathrm{~mm})$ one was obtained under the CK treatments in the same season. During the vegetative growth period, the RDI level showed no significant influence on the grape diameters, while, the grape size was significantly reduced during the reproductive growth period (Table 4). There was no significant difference of berry size showed between T50 and T25-50, but they were significantly larger than that of the T25 and $\mathrm{T} 50-25$.

\subsection{Effects of RDI on grape berry soluble solids}

The trends of the soluble solids were similar across the treatments and years (Table 4). In 2013, the soluble solid was significantly higher than that of the T50 treatment. There were no significant differences among the T25, CK and T50-25 treatments. The largest soluble solid was got under T50-25 treatment, at $24.83{ }^{\circ}$ Brix, compared to the T50 treatment, it improved by $12.38 \%$ for $\mathrm{T} 25,9.07 \%$ for $\mathrm{T} 25-50$ and $12.61 \%$ for $\mathrm{T} 50-25$. During the second and third years, the soluble solid of the T25-50 and T50 were present during the vine's reproductive growth period; they were significantly lower than that under the others. RDI applied during the entire growth period and the reproductive growth period had no significant effect on the soluble solid contents.

\subsection{Effects of RDI on reducing sugar, titratable acidity,} sugar/acid ratio and juice $\mathbf{p H}$

It could be observed that the reducing sugar content in grapes rose with increasing RDI gradient. Compared to T50, the three-year averaged reducing sugar content of T25 increased by $10.34 \%, 10.05 \%$ for $\mathrm{T} 50-25$ and $5.40 \%$ for T25-50. The reducing sugar content of the T50-25 was significantly higher than that of the T25-50, while no significant difference was showed among that of CK, T25 and T50-25.

The titratable acidity content increased with increasing RDI gradient (Table 4). However, T50 treatment the titratable acidity content was significantly higher than that of non-irrigation (CK). With the increase of RDI gradient, the Sugar/acid ratio first increased and then decreased. T25 treatment had the highest Sugar/acid ratio, with a three-year average of 39.75 .

There was no significant difference in the fruit juice $\mathrm{pH}$ among the treatments. With the regulated deficit increase, the $\mathrm{pH}$ generally decreased and peaked at 3.69 in the T50 treatment in 2014 and reached the minimum of 3.50 in the CK treatment in 2013.
Table 4 Parameters of grapes composition at harvest in different RDI treatments (450 samples)

\begin{tabular}{ccccc}
\hline Index & 2013 & 2014 & 2015 & Mean annual \\
\hline Berry size $/ \mathrm{mm}$ & & & & \\
\hline CK & $9.54 \pm 0.01 \mathrm{~d}$ & $9.83 \pm 0.01 \mathrm{c}$ & $9.90 \pm 0.02 \mathrm{~d}$ & $9.75 \pm 0.01 \mathrm{c}$ \\
T25 & $10.27 \pm 0.02 \mathrm{c}$ & $11.10 \pm 0.01 \mathrm{~b}$ & $10.50 \pm 0.03 \mathrm{c}$ & $10.62 \pm 0.02 \mathrm{~b}$ \\
T50-25 & $10.87 \pm 0.01 \mathrm{~b}$ & $11.15 \pm 0.01 \mathrm{~b}$ & $10.78 \pm 0.02 \mathrm{c}$ & $10.93 \pm 0.01 \mathrm{~b}$ \\
T25-50 & $11.98 \pm 0.02 \mathrm{a}$ & $11.98 \pm 0.03 \mathrm{a}$ & $11.58 \pm 0.01 \mathrm{~b}$ & $11.84 \pm 0.02 \mathrm{a}$ \\
T50 & $12.05 \pm 0.02 \mathrm{a}$ & $12.20 \pm 0.02 \mathrm{a}$ & $12.15 \pm 0.02 \mathrm{a}$ & $12.13 \pm 0.02 \mathrm{a}$ \\
\hline Soluble solids $\left({ }^{\circ}\right.$ Brix $)$ & & & \\
\hline CK & $24.93 \pm 0.44 \mathrm{a}$ & $24.83 \pm 0.16 \mathrm{a}$ & $24.38 \pm 0.33 \mathrm{a}$ & $24.71 \pm 0.28 \mathrm{a}$ \\
T25 & $24.78 \pm 0.32 \mathrm{a}$ & $24.38 \pm 0.32 \mathrm{a}$ & $24.15 \pm 0.37 \mathrm{a}$ & $24.43 \pm 0.33 \mathrm{a}$ \\
T50-25 & $24.83 \pm 0.15 \mathrm{a}$ & $24.53 \pm 0.41 \mathrm{a}$ & $24.50 \pm 0.27 \mathrm{a}$ & $24.62 \pm 0.29 \mathrm{a}$ \\
T25-50 & $24.05 \pm 0.37 \mathrm{~b}$ & $22.55 \pm 0.28 \mathrm{~b}$ & $23.20 \pm 0.16 \mathrm{~b}$ & $23.27 \pm 0.20 \mathrm{~b}$ \\
T50 & $22.05 \pm 0.29 \mathrm{c}$ & $22.10 \pm 0.32 \mathrm{~b}$ & $22.25 \pm 0.05 \mathrm{c}$ & $22.13 \pm 0.18 \mathrm{c}$ \\
\hline
\end{tabular}

\begin{tabular}{ccccc}
\hline Reducing sugar $/ \mathrm{g} \cdot \mathrm{L}^{-1}$ & & & \\
\hline CK & $292.75 \pm 7.25 \mathrm{a}$ & $288.75 \pm 2.35 \mathrm{a}$ & $291.00 \pm 0.94 \mathrm{a}$ & $290.83 \pm 3.01 \mathrm{a}$ \\
T25 & $290.00 \pm 2.24 \mathrm{a}$ & $285.50 \pm 3.21 \mathrm{a}$ & $289.75 \pm 0.92 \mathrm{a}$ & $288.08 \pm 2.54 \mathrm{a}$ \\
T50-25 & $287.50 \pm 2.31 \mathrm{a}$ & $284.75 \pm 0.69 \mathrm{a}$ & $288.75 \pm 1.72 \mathrm{a}$ & $287.33 \pm 1.75 \mathrm{a}$ \\
T25-50 & $274.75 \pm 1.19 \mathrm{~b}$ & $270.50 \pm 1.53 \mathrm{a}$ & $280.25 \pm 1.64 \mathrm{a}$ & $275.17 \pm 1.23 \mathrm{~b}$ \\
T50 & $262.75 \pm 1.24 \mathrm{c}$ & $257.25 \pm 3.76 \mathrm{c}$ & $263.25 \pm 2.58 \mathrm{~b}$ & $261.08 \pm 1.88 \mathrm{c}$
\end{tabular}

Titratable acidity $/ \mathrm{g} \cdot \mathrm{L}^{-1}$

\begin{tabular}{|c|c|c|c|c|}
\hline CK & $6.25 \pm 0.01 \mathrm{c}$ & $6.21 \pm 0.02 b$ & $6.41 \pm 0.07 b$ & $6.29 \pm 0.02 b$ \\
\hline $\mathrm{T} 25$ & $6.06 \pm 0.02 \mathrm{~d}$ & $6.09 \pm 0.02 \mathrm{c}$ & $6.30 \pm 0.01 b$ & $6.15 \pm 0.02 \mathrm{c}$ \\
\hline $\mathrm{T} 50-25$ & $6.32 \pm 0.01 \mathrm{c}$ & $6.21 \pm 0.01 b$ & $6.38 \pm 0.03 b$ & $6.30 \pm 0.01 b$ \\
\hline $\mathrm{T} 25-50$ & $6.63 \pm 0.03 b$ & $6.42 \pm 0.03 \mathrm{a}$ & $6.67 \pm 0.04 \mathrm{a}$ & $6.57 \pm 0.03 \mathrm{a}$ \\
\hline T50 & $6.98 \pm 0.04 \mathrm{a}$ & $6.43 \pm 0.02 \mathrm{a}$ & $6.84 \pm 0.06 \mathrm{a}$ & $6.75 \pm 0.03 \mathrm{a}$ \\
\hline \multicolumn{5}{|l|}{ sugar/acid ratio } \\
\hline $\mathrm{CK}$ & 39.89 & 39.98 & 38.03 & 39.30 \\
\hline $\mathrm{T} 25$ & 40.89 & 40.03 & 38.33 & 39.75 \\
\hline T50-25 & 39.29 & 39.50 & 38.40 & 39.06 \\
\hline $\mathrm{T} 25-50$ & 36.27 & 35.12 & 34.78 & 35.39 \\
\hline T50 & 31.59 & 34.37 & 32.53 & 32.83 \\
\hline \multicolumn{5}{|l|}{ Juice $\mathrm{pH}$} \\
\hline CK & $3.50 \pm 0.01 \mathrm{a}$ & $3.58 \pm 0.01 \mathrm{a}$ & $3.53 \pm 0.01 \mathrm{a}$ & $3.54 \pm 0.01 \mathrm{a}$ \\
\hline $\mathrm{T} 25$ & $3.55 \pm 0.00 \mathrm{a}$ & $3.60 \pm 0.02 \mathrm{a}$ & $3.58 \pm 0.00 \mathrm{a}$ & $3.58 \pm 0.01 \mathrm{a}$ \\
\hline T50-25 & $3.54 \pm 0.01 \mathrm{a}$ & $3.61 \pm 0.02 \mathrm{a}$ & $3.55 \pm 0.00 \mathrm{a}$ & $3.57 \pm 0.01 \mathrm{a}$ \\
\hline $\mathrm{T} 25-50$ & $3.60 \pm 0.00 \mathrm{a}$ & $3.66 \pm 0.01 \mathrm{a}$ & $3.58 \pm 0.03 \mathrm{a}$ & $3.62 \pm 0.01 \mathrm{a}$ \\
\hline T50 & $3.65 \pm 0.02 \mathrm{a}$ & $3.69 \pm 0.03 \mathrm{a}$ & $3.66 \pm 0.01 \mathrm{a}$ & $3.67 \pm 0.02 \mathrm{a}$ \\
\hline \multicolumn{5}{|c|}{ Total phenols $/ \mathrm{mg} \cdot \mathrm{g}^{-1}$} \\
\hline CK & $13.88 \pm 0.38 \mathrm{c}$ & $14.50 \pm 0.17 \mathrm{c}$ & $14.03 \pm 0.07 \mathrm{c}$ & $14.13 \pm 0.21 \mathrm{c}$ \\
\hline $\mathrm{T} 25$ & $14.93 \pm 0.24 b$ & $15.30 \pm 0.33 b$ & $14.93 \pm 0.12 b$ & $15.05 \pm 0.25 b$ \\
\hline T50-25 & $15.60 \pm 0.36 \mathrm{a}$ & $15.95 \pm 0.10 \mathrm{a}$ & $15.65 \pm 0.14 \mathrm{a}$ & $15.73 \pm 0.18 \mathrm{a}$ \\
\hline $\mathrm{T} 25-50$ & $14.88 \pm 0.09 \mathrm{~b}$ & $15.30 \pm 0.08 \mathrm{~b}$ & $15.03 \pm 0.22 b$ & $15.07 \pm 0.11 \mathrm{~b}$ \\
\hline T50 & $14.50 \pm 0.15 b$ & $14.80 \pm 0.02 b c$ & $14.70 \pm 0.08 \mathrm{~b}$ & $14.67 \pm 0.10 b$ \\
\hline \multicolumn{5}{|c|}{ Anthocyanins $/ \mathrm{mg} \cdot \mathrm{g}^{-1}$} \\
\hline CK & $6.22 \pm 0.06 \mathrm{c}$ & $6.16 \pm 0.10 \mathrm{~d}$ & $6.13 \pm 0.04 \mathrm{c}$ & $6.17 \pm 0.05 \mathrm{c}$ \\
\hline $\mathrm{T} 25$ & $6.43 \pm 0.11 \mathrm{~b}$ & $6.56 \pm 0.03 b$ & $6.55 \pm 0.05 b$ & $6.51 \pm 0.08 b$ \\
\hline T50-25 & $6.74 \pm 0.25 \mathrm{a}$ & $6.88 \pm 0.15 \mathrm{a}$ & $6.88 \pm 0.15 \mathrm{a}$ & $6.83 \pm 0.19 \mathrm{a}$ \\
\hline $\mathrm{T} 25-50$ & $6.43 \pm 0.06 \mathrm{~b}$ & $6.49 \pm 0.06 b$ & $6.51 \pm 0.06 \mathrm{~b}$ & $6.48 \pm 0.06 \mathrm{~b}$ \\
\hline T50 & $6.31 \pm 0.07 \mathrm{bc}$ & $6.28 \pm 0.12 c$ & $6.42 \pm 0.02 b c$ & $6.33 \pm 0.09 \mathrm{~b}$ \\
\hline \multicolumn{5}{|c|}{ Tannins $/ \mathrm{mg} \cdot \mathrm{g}^{-1}$} \\
\hline CK & $35.15 \pm 0.44 d$ & $37.48 \pm 0.06 \mathrm{c}$ & $36.53 \pm 0.08 \mathrm{~d}$ & $36.38 \pm 0.16 \mathrm{c}$ \\
\hline $\mathrm{T} 25$ & $37.53 \pm 0.32 \mathrm{c}$ & $40.28 \pm 0.05 b$ & $40.03 \pm 0.01 b c$ & $39.28 \pm 0.12 b$ \\
\hline T50-25 & $44.98 \pm 1.53 \mathrm{a}$ & $43.93 \pm 0.07 \mathrm{a}$ & $43.68 \pm 0.11 \mathrm{a}$ & $44.19 \pm 0.83 \mathrm{a}$ \\
\hline $\mathrm{T} 25-50$ & $42.18 \pm 0.13 b$ & $40.15 \pm 0.02 b$ & $40.65 \pm 0.02 b$ & $40.99 \pm 0.06 \mathrm{~b}$ \\
\hline $\mathrm{T} 50$ & $36.28 \pm 0.05 \mathrm{~cd}$ & $38.43 \pm 0.01 b c$ & $38.60 \pm 0.02 \mathrm{c}$ & $37.77 \pm 0.03 c$ \\
\hline
\end{tabular}

Note: Means within a column in the same year followed by the same letters are not significantly different $(p=0.05, n=5)$. 


\subsection{Effects of RDI on total phenols contents}

The T50-25 treatment had the largest total phenol content, which was significantly larger than that of the T50 treatment. Among all treatments, the first year's total phenol contents were less than that of both the second and third years. The order of the average total phenol content by decreasing was T50-25 $>\mathrm{T} 25-50>$ $\mathrm{T} 25>\mathrm{T} 50>\mathrm{CK}$ (Table 4), indicating that a moderate regulated deficit at post-veraison can improve the total phenol content in grape skin.

\subsection{Effects of RDI on anthocyanins contents}

The anthocyanin content increased with the increase of RDI level, and peaked at $6.88 \mathrm{mg} / \mathrm{g}$ under T50-25 at the third year. The peak value was significantly higher than that under T25 and T25-50 (Table 4). In all three years, the anthocyanin content in the CK treatment was the lowest and was significantly lower than others.

\subsection{Effects of RDI on tannin contents}

The tannin content initially increased and then decreased with the RDI increase throughout the study years. The average tannin contents under T50-25, T25 and T25-50 were larger than that under T50, among which the largest content obtained under T50-25 with $44.19 \mathrm{mg} / \mathrm{g}$. Compared to the T50, the average tannin contents of T25 improved by $4.0 \%$, by $17.0 \%$ in T50-25 and $8.5 \%$ in T25-50, while no significant differences between the T25 and T25-50 (Table 4). The average tannin content was listed as T50-25 > $\mathrm{T} 25-50>\mathrm{T} 25>\mathrm{T} 50>\mathrm{CK}$.

\section{Discussion}

The climate usually can not affect the vine growth and berry composition $^{[10]}$. The role of deficit irrigation will be especially affected when the rainfall was different from each year ${ }^{[29]}$. In this study, although the rainfall amount in 2013 was higher than that in 2014 and 2015, the rainfall distribution and tendency were similar (Figure 1), therefore, the effects of rainfall on deficit irrigation in this study can be ignored.

The effects of water stress on grape LWP was showed in the water potential in each part of the plant, in which LWP is the most direct indicator of whole plant water status as it represents the energy level of water movement, it also showed the restrictions of water status on plant physiological activities at each growth stage. The plant LWP would be affected by soil moisture, temperature, air humidity, photosynthetically active radiation and leaf transpiration rate and so on. The LWP is usually positively related to soil water content, and largely affected by transpiration rate ${ }^{[12,30]}$. In this study, the grape LWP decreased linearly with soil water content after irrigation until watered again. During the flowering stage, the LWP of treatments with higher water deficit level decreased quicker, the LWP was relatively higher due to the low water requirement at veraison compared to flowering stage.

The response of the grapevine to water supply variations was slow, and the annual variability might mask the true differences between the treatments; therefore, this response should be assessed in a long-term context. The implementation of RDI programs in wine grapes has been extensively proposed as a solution to increase the water productivity while reducing irrigation water use ${ }^{[31,32]}$. In many areas it was considered as the right way to obtain the desired quality of production. From the 3-years study, it was founded that the vegetative growth estimated via the plant shoots was less sensitive than the yield components to variations of water availability. Therefore, the water availability substantially affected the grape growth with significant differences recorded in the final year of the study. These results demonstrate that the RDI negatively affected grape plant development but no effects on grape composition. Thus, the application of RDI can restrain grape vegetative growth but still produce high-quality grapes for wine making. However, excessive deficit irrigation strategies were considered detrimental to the canopy development and fruit sustainability production ${ }^{[33]}$. Grape leaves are the basis of grapevine photosynthesis, and leaf development indicators determine the yield and grape composition ${ }^{[34]}$. When grapevine was threatened with severe drought during their vegetative periods, the metabolism will change, and consequently, will affect productivity ${ }^{[35,36]}$. Moderate drought stress can reduce the vine growth of the aboveground vegetative organs and can enhance the root-top ratio, while severe drought stress can significantly restrict the growth of grape vine roots ${ }^{[2,37]}$. It Was founded that the average shoots of T25, T50-25 and T25-50 were significantly higher than that of $\mathrm{CK}$, but no significant difference among each other.

In areas with limited irrigation, pre- and post-veraison, the LWP indicated midday water stress, which was beneficial for grape growth, inflorescence differentiation and floral bud differentiation. In some studies regarding the application of water stress to Riesling and Pinot Noir vine varieties during different growth periods in China, the results showed that increased water stress restricted branch development and reduced the leaf area and berry weight ${ }^{[37]}$. Other studies have also demonstrated that RDI applied during flowering stage can thin the flowers and optimize the spatial distribution of grape clusters; however, the yield decreased by $12 \%{ }^{[38]}$. When RDI is applied during the post-growth period, the growth was not observed within the same year, and the yield decreased slightly ${ }^{[23]}$. The results in this study indicated that differences were observed from the first year and increased throughout the following years. The berry size reduction caused by water restriction during the reproductive stage was not completely offset by increasing water during the vegetative growth stage. The reduction in the berry size at harvest did not lead to a significantly lower yield. This feature indicates that the reduction in the berry size in the RDI treatments was most likely due to both the lower vine water status and a higher on-cluster sink demand. A mild reduction in the vine water status might decrease the shoot length favoring berry set in a fashion similar to that of shoot topping performed around the fruit set ${ }^{[22,39,40]}$. Until the third year of the experiment, the berry diameters decreased as the RDI increased, therefore, induced the decreased yield. The individual grape yield under RDI applied during the reproductive period was significantly lower than that applied during the vegetative growth period. This is in accordance to the report that the pre-veraison water deficit is more critical than post-veraison ${ }^{[26]}$. The vegetative growth stage has the most sensitive plant response to water deficit, during which higher RDI would restrict new shoot length, therefore, was more beneficial for nutrient accumulation and transformation to berries. Implementing RDI during vegetative growth can make the leaf thinner and lighter in color ${ }^{[17]}$.

The water content plays an important role in grape composition. The sugar content, acidity, sugar/acid ratio and phenol contents are all key factors for grape composition ${ }^{[34]}$. Former researchers ${ }^{[41]}$ demonstrated that RDI applications decreased the grape yield by $13.8 \%$, and the reducing sugar content and sugar/acid ratio in the grapes increased, the total acid content decreased, and the tannin and total phenol contents increased ${ }^{[19]}$. It was founded in this study that the soluble solid contents in all of the treatments were 
significantly larger than that of the T50, however, the effects of CK, T25 and T50-25 treatment on soluble solids content were not significant in the whole growth period and reproductive growth period. It suggests that the berry soluble solid and sugar contents positively correlate with total sugar content, accounting for $60 \%-80 \%$ of soluble solid contents ${ }^{[17]}$. Under water stress, the soluble sugar content in berries increased, and some special sugar for osmotic adjustment increased ${ }^{[35]}$. This study demonstrates that the grapes from the non-irrigated vines had a higher concentration of mean annual soluble solids than others due to intense dehydration. Under all of the RDI treatments, the soluble solid and reducing sugar contents decreased, the total acid content increased, and the sugar/acid ratio basically showed a downward trend.

The most striking differences in the grape composition between the irrigated treatments were anthocyanin concentration ${ }^{[42]}$ Researchers showed that implementing RDI between germination and the first-flowering period can improve the contents of inner composition indicators, such as soluble solids, total sugar and vitamin $\mathrm{C}$; moreover, applying RDI during the berry-coloring period was beneficial for improving the berry outer quality, namely, the anthocyanin contents in the berry $\operatorname{skin}^{[26]}$. However, significant differences were observed for different RDI treatments in this study, highlighting the greater influence of irrigation strategy than water volume. In terms of water restriction and irrigation timing, the major differences between T50-25 and T25-50 indicated that deficit irrigation during the vegetative growth stage is less critical for the berry compound compared with deficit irrigation applied during the reproductive stage.

Moderate water stress can strengthen the berry pigmentation degree and sweetness, thereby improving berry quality, which are in accordance with previous findings from a study with an experiment site also in Tempranillo vines (Spain), in which the post-veraison water stress was more effective than pre-veraison water deficit for increasing the berry anthocyanin content ${ }^{[43]}$. It was also founded that the anthocyanin content of the T50-25 was significantly higher than that of the T25 and T25-50 treatments, and that of the CK treatment was the lowest during the whole study period. The water stress experienced by the vines post-veraison appeared to be too severe to increase the anthocyanin and berry sugar concentrations, which is consistent with previous studies ${ }^{[43]}$.

Several studies concluded that the extractability of anthocyanins is lower in grapes from highly irrigated vines due to either delayed ripening or thicker berry cell walls ${ }^{[14]}$. As regulated deficit increased, both the total phenol and anthocyanin contents increased initially and then decreased, indicating that a small regulated deficit is helpful for improving the phenol compounds contents, such as phenols in berry skins. The results indicate that the effect of the water status on the anthocyanin concentration was greater than that exerted on the berry size. This study also demonstrates that a moderate regulated deficit during post-veraison can improve the total phenol content in grape skin, and moderate RDI can improve tannin content in the grape skins.

Collectively, it is worthy to note that water stress at post-veraison is recommended in cases where wine aimed with lower alcohol content, because this irrigation strategy did not lead to any clear advantage in terms of grape composition. Therefore, the applied irrigation strategy will ultimately depend on the vineyard owner's and winemaker's goals as well as the available volumes of irrigation water.

\section{Conclusions}

Moderate regulated deficit irrigation can significantly increase grape skin total phenol, tannin, and anthocyanin contents while promoting the promotion of soluble solids and the reduction of titrable acids in grape berries. Based on the results of berry composition, the treatment irrigated at 50\% ETc until veraison and $25 \%$ thereafter was considered to be the most efficient irrigation strategy in this area.

\section{Acknowledgements}

This work was supported by the Key R\&D Plan of Ningxia (2016BZ06), Western Top Disciplines Construction Project of Horticulture (NXYLXK2017B03) and the National Natural Science Foundation of China (31460552). We thank our colleagues for their comments regarding this paper and the journal's editors and anonymous reviewers for their critical reviews and comments regarding this manuscript.

\section{[References]}

[1] Vaudour E, Costantini E, Jones G V, Mocali S. An overview of the recent approaches to terroir functional modelling, footprinting and zoning. Soil, 2015; 1(1): 287-312.

[2] Brevik E C. The interdisciplinary nature of soil. 2015; 1(1): 117-129.

[3] Keesstra S D, Bouma J, Wallinga J, Tittonell P, Smith P, Cerdà A, et al. The significance of soils and soil science towards realization of the United Nations Sustainable Development Goals. Soil, 2016; 2(2): 111-128.

[4] Costa J M, Ortuno M F, Chaves M M. Deficit irrigation as a strategy to save water: physiology and potential application to horticulture. Journal of Integrative Plant Biology, 2007; 49(10): 1421-1434.

[5] Ezzhaouani A, Valancogne C, Pieri P, Amalak T, Gaudillère J P. Water economy by Italia grapevines under different irrigation treatments in a Mediterranean climate. International Journal of Vine and Wine Sciences, 2007; 41(3): 131-139.

[6] Fang Y L, Sun W, Wan L, Xi Z M, Liu X, Zhang Z W. Effects of regulated deficit irrigation (RDI) on wine grape growth and fruit quality. Scientia Agricultura Sinica, 2013; 46(13): 2730-2738.

[7] García J G, Martínez-Cutillas A, Romero P. Financial analysis of wine grape production using regulated deficit irrigation and partial-root zone drying strategies. Irrigation Science, 2012; 30(3): 179-188.

[8] Ortega-Farias S, Fereres E, Sadras V O. Special issue on water management in grapevines. Irrigation Science, 2012; 30(5): 335-337.

[9] Chaves M M, Santos T P, Souza C R, Ortuño M F, Rodrigues M L, Lopes $\mathrm{C} \mathrm{M}$, et al. Deficit irrigation in grapevine improves water-use efficiency while controlling vigour and production quality. Annals of Applied Biology, 2007; 150(2): 237-252.

[10] Lorenzo M N, Taboada J J, Lorenzo J F, Ramo A M. Influence of climate on grape production and wine quality in the Rías Baixas, north-western Spain. Regional Environmental Change, 2012; 13: 887-896.

[11] Van L C, Tregoat $O$, Chonè X, Bois B, Pernet D, Gaudillère J P. Vine water status is a key factor in grape ripening and vintage quality for red bordeaux wine. How can it be assessed for vineyard management purposes? Journal International des Sciences de la Vigne et du Vin, 2009; 43: 121-134.

[12] Pellegrino A, Lebon E, Voltz M, Wery J. Relationships between plant and soil water status in vine (Vitis vinifera L.). Plant and Soil, 2005; 266(1-2) $129-142$.

[13] Castellarin S D, Pfeiffer A, Sivilotti P, Degan M, Peterlunger E, Gaspero G D. Transcriptional regulation of anthocyanin biosynthesis in ripening fruits of grapevine under seasonal water deficit. Plant, Cell and Environment, 2007; 30(11): 1381-1399.

[14] Romero P, Fernández J I, Martínez-Cutillas Adrián. Physiological thresholds for efficient regulated deficit-irrigation management in winegrapes grown under semiarid conditions. American Journal of Enology and Viticulture, 2010; 61(3): 300-312.

[15] Intrigliolo D S, Castel J R. Interactive effects of deficit irrigation and shoot and cluster thinning on grapevine cv. Tempranillo. Water relations, vine performance and berry and wine composition. Irrigation Science, 2011; 29(6): 443-454. 
[16] Egea G, Nortes P A, González-Real M M, Baille A, Domingo R. Agronomic response and water productivity of almond trees under contrasted deficit irrigation regimes. Agricultural Water Management, 2010; 97(1): 171-181.

[17] Santesteban L G, Miranda C, Royo J B. Regulated deficit irrigation effects on growth, yield, grape quality and individual anthocyanin composition in Vitis vinifera L. cv. 'Tempranillo'. Agricultural Water Management, 2011; 98(7): 1171-1179.

[18] Casassa L F, Larsen R C, Beaver C W, Mireles M S, Keller M, Riley W R, et al. Impact of extended maceration and regulated deficit irrigation (RDI) in Cabernet Sauvignon wines: characterization of proanthocyanidin distribution, anthocyanin extraction, and chromatic properties. Journal of Agricultural and Food Chemistry, 2013; 61(26): 6446-6457.

[19] Intrigliolo D S, Juan Ramón Castel. Response of grapevine cv. 'Tempranillo' to timing and amount of irrigation: water relations, vine growth, yield and berry and wine composition. Irrigation Science, 2010; 28(2): 113-125

[20] Leeuwen C V. Influence of climate, soil, and cultivar on terroir. American Journal of Enology and Viticulture, 2004; 55(3): 207-217.

[21] Chaves M M, Zarrouk O, Francisco R, Costa J M, Santos T, Regalado A P, et al. Grapevine under deficit irrigation: hints from physiological and molecular data. Annals of Botany, 2010; 105(5): 661-676.

[22] Faci J M, Blanco O, Medina E T, Martínez-Cob A. Effect of post veraison regulated deficit irrigation in production and berry quality of Autumn Royal and Crimson table grape cultivars. Agricultural Water Management, 2014; 134: 73-83.

[23] Edwards E J, Clingeleffer P R. Interseasonal effects of regulated deficit irrigation on growth, yield, water use, berry composition and wine attributes of Cabernet Sauvignon grapevines. Australian Journal of Grape and Wine Research, 2013; 19(2): 261-276.

[24] Niculcea M, López J, Sánchez-Díaz M, Carmen Antolín M. Involvement of berry hormonal content in the response to pre- and post-veraison water deficit in different grapevine (Vitis vinifera L.) cultivars. Australian Journal of Grape and Wine Research, 2014; 20(2): 281-291.

[25] Romero P, Gil-Muñoz Rocío, Del Amor F M, Valdés E, Fernández J I, Martínez-Cutillas Adrián. Regulated deficit irrigation based upon optimum water status improves phenolic composition in Monastrell grapes and wines. Agricultural Water management, 2013; 121: 85-101.

[26] Ojeda H, Andary C, Kraeva E, Carbonneau A, Deloire A. Influence of pre-and postveraison water deficit on synthesis and concentration of skin phenolic compounds during berry growth of Vitis vinifera cv. Shiraz. American Journal of Enology and Viticulture, 2002; 53(4): 261-267.

[27] Allen R G, Pereira L S, Raes D, Smith M. Crop evapotranspirationguidelines for computing crop water requirements-FAO Irrigation and drainage paper 56. FAO, Rome, 1998; 300(9): D05109.

[28] Harbertson J F, Picciotto E A, Adams D O. Measurement of polymeric pigments in grape berry extract sand wines using a protein precipitation assay combined with bisulfite bleaching. American Journal of Enology and Viticulture, 2003; 54(4): 301-306

[29] Rodrigo Comino J, Brings C, Lassu T, Iserloh T, Senciales J M, Martínez Murillo J F, et al. Rainfall and human activity impacts on soil losses and rill erosion in vineyards (Ruwer Valley, Germany). Solid Earth, 2015; 6(3): 823-837.

[30] Tyree M T. The forgotten component of plant water potential: A reply-tissue pressures are not additive in the way MJ Canny suggests. Plant Biology, 1999; 1(6): 598-601.

[31] Egea G, Nortes P A, Domingo R, Baille A, Pérez-Pastor A, Alejandro M M et al. Almond agronomic response to long-term deficit irrigation applied since orchard establishment. Irrigation Science, 2013; 31(3): 445-454.

[32] Girona J, Mata M, Marsal J. Regulated deficit irrigation during the kernel-filling period and optimal irrigation rates in almond. Agricultural Water Management, 2005; 75(2): 152-167.

[33] Pérez-Pérez J G, García J, Robles J M, Botía P. Economic analysis of navel orange cv. 'Lane late' grown on two different drought-tolerant rootstocks under deficit irrigation in South-eastern Spain. Agricultural Water management, 2010; 97(1): 157-164.

[34] He P C. Grape Science. Beijing, China Agriculture Press. 1999; pp.95-97. (in Chinese)

[35] Greven M, Green S, Neal S, Clothier B, Neal M, Dryden G, et al. Regulated Deficit Irrigation (RDI) to save water and improve Sauvignon Blanc quality. Water Science and Technology, 2005; 51(1): 9-17.

[36] Sun X Z, Zheng C S, Wang X F. Advances of drought tolerant mechanism in woody plant. Acta Botanica Boreali-Occidentalia Sinica, 2007; 27: 629-634. (in Chinese)

[37] Qi W, Li E M, Zhai H, Wang X F, Du Y P, Tan H. Effects of partial rootzone drying on the growth of Vitis vinifera $\mathrm{cv}$. malvasia grafted on varied root stocks. Scientia Agricultura Sinica, 2007; 40(4): 794-799.

[38] Liu H G, He X L, Wang Y Q, Yang H H. Effects of regulated deficit irrigation on growing and yield of drip irrigated drip irrigated. Journal of Shihezi University, 2010; 28: 610-613. (in Chinese)

[39] Ramos M C, Jones G V, Martínez-Casasnovas J A. Structure and trends in climate parameters affecting wine grape production in northeast Spain. Climate Research, 2008; 38: 1-15.

[40] Romero P, Martínez-Cutillas A. The effects of partial root-zone irrigation and regulated deficit irrigation on the vegetative and reproductive development of field-grown Monastrell grapevines. Irrigation Science, 2012; 30(5): 377-396.

[41] Loveys B R, Dry P R, Stoll M, McCarthy M G. Using plant physiology to improve the water use efficiency of horticultural crops. In III International Symposium on Irrigation of Horticultural Crops, 1999; 537: 187-197.

[42] Fereres E, Soriano M A. Deficit irrigation for reducing agricultural water use. Journal of Experimental Botany, 2007; 58(2): 147-159.

[43] Girona J, Marsa J, Mata M, Campo J D, Basile B. Phenological sensitivity of berry growth and composition of Tempranillo grapevines (Vitis vinifera L.) to water stress. Australian Journal of Grape and Wine Research, 2009; 15(3): 268-277. 